JANsson, G., A. Jonsson and G. ERIKsson (1998): Efficiency of early testing in Pinus sylvestris L., grown under two different spacings in growth chamber. Silvae Genet. 47: 298-306.

Joly, R. J., W. T. Adams and S. G. Stafford (1989): Phenological and morphological responses of mesic and dry sites sources of coastal Douglas-fir to water deficit. For Sci. 35: 987-1005.

LAMBETH, C. C. (1980): Juvenile-mature correlations in Pinaceae and implication for early selection. Forest Sci. 26: $571-580$.

Lambeth, C. C. and L. A. Dill (2001): Prediction models for juvenile-mature correlations for loblolly pine growth traits within, between and across test sites. Forest Genetics. 8(2): 101-108.

LEVIA, D. F. (2008): A generalized allometric equation to predict foliar dry weight on the basis of trunk diameter for eastern white pine (Pinus strobus L). For Ecol Manag. 255(5/6): 1789-1792.

Li, B., G. C. Williams, W. C. Carlson, C. A. Harrington and C. C. LAMBETH (1992): Gain efficiency in short term testing: Experimental results. Can J For Res. 22: 290-297.

MuUkKonen, P. (2007): Generalized allometric volume and biomass equations for some tree species in Europe. Eur J For Res. 126(2): 157-166.

Muñoz, M. (2008): Silvicultura de Pinus radiata D. Don. Editorial Universidad de Talca. Talca.

Sánchez, M. V., J. G. Salazar, J. J. Vargas, U. López and J. JASSO (2003): Parámetros genéticos y respuesta a la selección en características del crecimiento de Cedrela odorata L. Rev Fitotec Mex. 26(1): 19-27.
Shaiek, O., D. Loustau, P. Trichet, C. Meredieu, B. BachtobJi, S. Garchi and M. H. El Aouni (2011): Generalized biomass equations for the main aboveground biomass components of maritime pine across contrasting environments. Ann For Sci. 68: 443-452.

Sonesson, J., G. JANSson and G. ERIKSson (2002): Retrospective genetic testing of Picea abies under controlled temperature and moisture regimes. Can J For Res. 32: 81-91.

SONESSON, J. and G. ERIKSSON (2003): Genetic variation in drought tolerance in Picea abies seedlings and its relationship to growth in controlled and field environments. Scand J For Res. 18: 7-18.

TAN, W., T. J. Blake and T. J. B. Boyle (1995): Early selection for drought tolerance and relationship to dry weight partitioning in black spruce families. For Sci. 41: $168-180$.

Wu, H. X., M. Ivković, W. J. Gapare, A. C. Matheson, B. S. Baltunis, M. B. Powell and T. A. McRae (2008): Breeding for wood quality and profit in Pinus radiata: A review of genetic parameter estimates and implications for breeding and deployment. NZ J For Sci. 38(1): 56-87.

ZAS, R. and J. FERNÁNDEZ-LÓPEZ (2005): Juvenile genetic parameters and genotypic stability of Pinus pinaster Ait. open-pollinated families under different water and nutrient regimes. For Sci. 51: 165-174.

ZAS, R., E. MerLo and J. Fernández-LóPez (2004): Juvenile - Mature Genetic Correlations in Pinus pinaster Ait. Under Different Nutrient x Water Regimes. Silvae Genet. 53: 124-129.

Zobel, B. and J. TALBERT (1984): Applied forest tree improvement. John Wiley \& Sons, USA.

\title{
Aspects of sexual reproduction in rare monoecious Populus nigra var. nigra trees
}

\author{
By K. NovotnÁ ${ }^{\left.1,2,{ }^{, *}\right)}$ and P. ŠToCHLOVÁ ${ }^{11}$
}

(Received 21 $1^{\text {th }}$ September 2012)

\begin{abstract}
Individuals of the genus Populus are mostly dioecious, although deviations from strict dioecism occasionally occur. The aim of this study was to determine whether six, rare monoecious Populus nigra var. nigra trees,

1) Silva Tarouca Research Institute for Landscape and Orna mental Gardening, Publ. Res. Inst., Květnové náměstí 391, CZ-252 43 Průhonice, Czech Republic.

E-Mail: novotna@vukoz.cz, stochlova@vukoz.cz.

2) Czech University of Life Sciences Prague, Faculty of Forestry and Wood Sciences, Kamýcká 1179, CZ-165 21 Praha 6 - Suchdol, Czech Republic. E-Mail: novotna@fld.czu.cz.

*) Corresponding author: Kateřina Novotná. Phone: +420 296 528 378, fax: +420 267750 440. E-Mail: novotna@vukoz.cz.
\end{abstract}

identified in trial plots, were fertile and capable of sexually reproducing. Controlled pollinations were carried out and compared with the results of open pollination. Viable seeds were obtained from all combinations of pollination possibilities, suggesting these monoecious trees could be used as either male or female parent and were self-fertile. However, no individuals produced by selfpollination were found among the offspring from openpollinated, monoecious trees. The parentage of some of the crosses was verified using microsatellite markers. The germination energy (GE) and germination capacity (GC) were in most cases higher for seeds produced from controlled pollinations than from open pollination. Furthermore, GE and GC were both higher when pollen from the monoecious trees was used. An association 
between GE and GC rates on the one hand, and the pollination method and year it took place on the other, was found in most crosses made. This study extends knowledge of the reproductive biology of $P$. nigra that could be utilized in conservation genetic of this endangered allogamous species.

Key words: Black poplar; germination capacity; germination energy; microsatellite markers; monoecism; paternity, controlled pollination.

\section{Introduction}

Black poplar (Populus nigra L.) is a member of the genus, Populus, that comprises 29 species (STETTLER et al., 1996), most of which are native to the Northern Hemisphere. Poplars are mostly dioecious and obligatory outcrossers, with the exception of Populus lasiocarpa Oliv., a monoecious, self-fertilizing species assigned to the section Leucoides (FAO, 1980).

Dioecism automatically ensures obligatory outcrossing and so avoids the deleterious effects of inbreeding depression, and at the same time promotes heterozygosity, genetic variability, and genetic exchange, all of which are advantageous for the long-term survival and adaptation of a species (DELlAPORTA and CALDERONURREA, 1993). Gender variation has been described in various different dioecious plant species (HUFF and WU, 1992; HUMEAU et al., 1999; HUMEAU et al., 2000; AGUIRRE et al., 2007; İSFENDIYAROĞLU and ÖzEKER, 2009) and the occasional occurrence of monoecious trees has also been reported in several different species of genus Populus (CRONK, 2005), with deviations from strict dioecism found in individual trees and catkins. These include: Populus alba L. (AlBA et al., 2008) and Populus tremuloides Michx. (SANTAMOUR, 1956; LeSTER, 1963) in the section Leuce, Populus euphratica Olivier (RoTTEnBERG, 2000) in the section Turanga, Populus trichocarpa Torrey \& A. Gray (STETTLER, 1971; Slavov et al., 2009) in the section Tacamahaca, and Populus deltoides Bartr. Ex Marsh. (CAMPO, 1963), Populus deltoides var. wislizenii (Rowland et al., 2002), Populus nigra var. betulifolia (Pursh) Torr. (VoN MELCHIOR, 1967) and Populus nigra var. thevestina (Dode) Bean (Jovanović and Tucović, 1962) in the section Aigeiros. No published records of deviation from dioecism by Populus nigra var. nigra have been found in the relevant literature, but nevertheless during the course of other investigations (specifically, sex determination in flowering plants,) it was observed that monoecious individuals were present in the trial plantations at our research institute.

The atypical monoecious flowers vary in their abundance, sometimes occurring as occasional, isolated flowers in a few, rare inflorescences, but in other instances through-out some or even all of the catkins on a given tree. They may re-occur year after year, or only in particular years, and their frequency may also vary markedly from one year to another (STETTLER, 1971; RowLAND et al., 2002). It has also been reported that pollen fertility and fruit production is poorer than for ordinary unisexual individuals (ROTTENBERG, 2000). Furthermore, these unusual flowers appear to be selfcompatible (VON MELCHIOR, 1967; RowlAND et al., 2002).

The exact causes of deviations from strict dioecism are unknown (BRUNNER, 2010), but in the literature there are various interpretations and theories, based on different assumptions. Variation from strict dioecism occurs more frequently in small fragmented or peripheral populations than in un-disturbed central ones (HUFF and Wu, 1992; HuMEAU et al., 1999). Gender variation is often explained as a reaction to ecological differences and/or an environment (BARRETT, 1992; HUMEAU et al., 2000; CASE and Barrett, 2001; DelPh and Wolf, 2005). Jovanović and Tucović (1962) explained them as somatic mutations of adventitious buds, caused by some kind of traumatic injury, and HESLOP-HARRISON (1924) attributed hermaphrodite forms of Salix species to infestations of Eriophyd mites.

The aim of this work was to find out whether monoecious Populus nigra var. nigra trees were capable of sexual reproduction, either by self-pollination using male and female flowers occurring on the same tree or by cross pollination with other trees using either the male or female flowers. The results of this study will improve knowledge of the reproductive biology of $P$. nigra var. nigra that could be utilized in conservation genetic.

\section{Material}

In the course of the years 2009-2011, the sex of the $P$. nigra var. nigra trees was determined in the stand that is located in the grounds of the Silva Tarouca Research Institute for Landscape and Ornamental Gardening, in Central Bohemia $\left(50^{\circ} 00^{\prime} \mathrm{N}, 1^{\circ} 33^{\prime} \mathrm{E}\right.$ and 306 a.s.l) (Table 1). The stand was established using 1-yearold seedlings, derived from both controlled and open pollination of relatives of three female trees (BENETKA et al., 2008), in the spring of 2003. Plant spacing was $0.45 \times 2 \mathrm{~m}$.

Among 234 living trees, 6 monoecious trees $\left(\mathrm{Me}_{1}, \mathrm{Me}_{2}\right.$, $\mathrm{Me}_{3}, \mathrm{Me}_{4}, \mathrm{Me}_{5}, \mathrm{Me}_{6}$ ) were found, all of which were healthy. All monoecious trees in the stand came from the same mother tree, with the exception of tree $\mathrm{Me}_{2}$ (Table 1). Four of the monoecious trees $\left(\mathrm{Me}_{1}, \mathrm{Me}_{2}, \mathrm{Me}_{4}\right.$ and $\mathrm{Me}_{6}$ ) were derived from controlled pollinations using a sibling male tree, another $\left(\mathrm{Me}_{5}\right)$ from controlled pollination using a mixture of pollen from unrelated male trees, and the last $\left(\mathrm{Me}_{3}\right)$ from open pollination. Three

Table 1. - Summary of $P$. nigra sex distribution.

\begin{tabular}{cccccc}
\hline $\begin{array}{c}\text { Mother trec } \\
\text { designation }\end{array}$ & $\begin{array}{c}\text { Number of living } \\
\text { descendants }\end{array}$ & \multicolumn{4}{c}{ Number of flowering descendants } \\
\hline 2 & 77 & 22 & 41 & 5 & not flowering \\
3 & 46 & 7 & 28 & 1 & 10 \\
5 & 111 & 36 & 51 & - & 24 \\
\hline
\end{tabular}



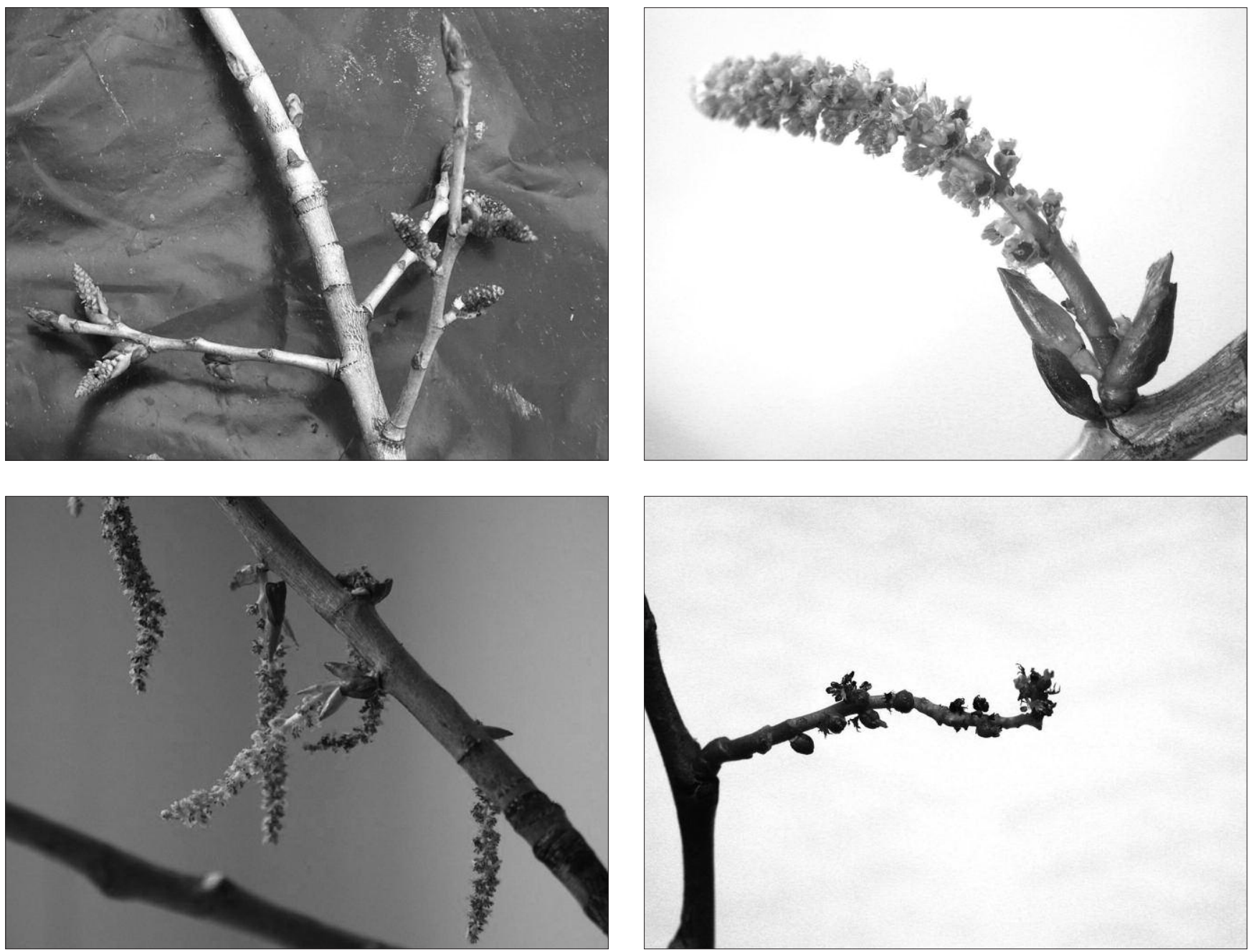

Figure 1. - Flowers from a monoecious black poplar tree: (a) female and male catkins on one monoecious tree branch; (b-e) female and male flowers on one catkin [(b) just before flower opening; (c) opening (receptive) flowers; (d) fruits].

different types of inflorescence were observed on these trees: wholly female catkins, wholly male catkins, and catkins bearing both male and female flowers (Figure 1). There appeared to be no obvious pattern to their positioning, either within the catkins themselves or within the tree.

The first two trees $\left(\mathrm{Me}_{1}\right.$ and $\left.\mathrm{Me}_{2}\right)$ were found by chance in 2009, when branches bearing flower buds were taken to provide pollen for a breeding programme. On the spur of the moment, it was decided to use the branches of the $\mathrm{Me}_{1}$ tree for a self-pollination (i.e. selfing, $\mathrm{Me}_{\mathrm{x}} \times \mathrm{Me}_{\mathrm{x}}$ treatment) experiment, and afterwards the sex of all the flowering trees in the stand were assessed over a 3 year period. The seeds originated from open pollination ( $\mathrm{Me}_{\mathrm{x}}{ }^{\mathrm{OP}}$ treatment) of $\mathrm{Me}_{1}$ and $\mathrm{Me}_{2}$ trees were also included to the experiment.

In the spring of 2010 the $\mathrm{Me}_{1}$ tree was used to make four different crossings: (1) self-pollination $\left(\mathrm{Me}_{\mathrm{x}} \times \mathrm{Me}_{\mathrm{x}}\right.$ treatment), (2) crossing with a sibling male tree $\left(\mathrm{Me}_{\mathrm{x}} \times \mathrm{B}\right.$ treatment) and (3) crossing with a sibling female tree $\left(\mathrm{S} \times \mathrm{Me}_{\mathrm{x}}\right.$ treatment), (4) open pollination ( $\mathrm{Me}_{\mathrm{x}}{ }^{\mathrm{OP}}$ treatment).

The $\mathrm{Me}_{2}$ tree did not blossom in this year, due to the large number of branches removed in the previous year.
Three other monoecious trees were found $\left(\mathrm{Me}_{3}, \mathrm{Me}_{4}\right.$ and $\mathrm{Me}_{5}$ ) but due to the small number of flowers they carried, only fruits derived from open pollination $\left(\mathrm{Me}_{\mathrm{x}}{ }^{\mathrm{OP}}\right.$ treatment) could be harvested.

In 2011, the same matings as in 2010 were made when enough of both male and female flowers could be found. Furthermore, crossings with only distantly related or un-related trees $\left(\mathrm{Me}_{\mathrm{x}} \times \mathrm{O}\right.$ treatment) were made when possible, and another monoecious tree $\left(\mathrm{Me}_{6}\right)$ was found. In 2009, both the GE and GC of seeds derived from $\mathrm{Me}_{6}$ open pollination ( $\mathrm{Me}_{\mathrm{x}}$ OP treatment) were investigated for another purpose.

\section{Methods}

\section{The pollination process}

Branches with flower buds were cut from selected trees. For collecting pollen, the branches were put in a glass containing tap water and then placed in separate rooms at about $20^{\circ} \mathrm{C}$. The pollen was then collected and, after drying, stored in a refrigerator at $4{ }^{\circ} \mathrm{C}$.

The branches bearing female flowers to be pollinated were also placed in water and then put in a greenhouse. Flowering branches were isolated with paper bags 
before the stigmas became receptive. Pollination was achieved by using a rubber balloon to blow pollen through a small hole into the paper bags, with the hole subsequently being sealed with a sticker. This procedure was performed four times. The paper bags were taken off four days after the first pollination.

As a comparison, several open-pollinated branches from the respective monoecious trees were (randomly) collected in the stand when the size of the fruits was around $4 \mathrm{~mm}$. The branches were placed in a glass with tap water and put in the same greenhouse as the branches used for the controlled pollination experiments.

\section{Seed collection}

Unripe capsules from controlled- and open-pollinated flowers were placed in sheer stiff muslin sacks just before seed releasing (ca 20 days following pollination), and the seeds which were subsequently released were stored for three days to fully ripen. Then the seeds were placed in sieves and separated from the silky hairs by a jet of compressed air.

\section{Trial evaluation}

The seeds obtained were counted and subsequently sown on the surface of wet peat in boxes, which were then placed in a greenhouse with high humidity and a temperature no higher than $20^{\circ} \mathrm{C}$. The germination energy and the germination capacity of each pollination combination were then calculated.

Germination energy (GE) is defined as the percentage of seeds germinating three days after sowing. Germination capacity (GC) is defined as the percentage of seedlings with two foliage leaves ten days after sowing. These parameters were calculated using a minimum of 100 seeds for each variant whenever possible. Since capsules ripened progressively, it was necessary in some cases to harvest seeds more than once from any given branch, and in these instances the parameters of germination were calculated by using a weighted average.

\section{Statistical analysis}

The data were analysed using the statistical software package Statistica 9.0 (STATSOFT, INC., 2009). The associations between germination energy and capacity, and the various types of pollinations, including different years, were analysed using Pearson's Chi-square test of significance $(\alpha<0.05)$ and the strength of these associations was assessed using Cramer's V coefficient.

\section{Genetic analysis}

Parentage was verified by taking fresh leaves from the parent trees and 124 of the descendants derived from the various different crossings. Fresh leaves were collected from selected monoecious trees $\left(\mathrm{Me}_{1}, \mathrm{Me}_{2}\right)$ to detect mutation chimera (RUDRÍGUEZ LóPEZ et al., 2004), three from each cardinal point (W, S, E), and frozen in liquid nitrogen. Genomic DNA was isolated from the leaf samples using a DNeasy Plant Mini Kit (Qiagen), in line with the manufacturer's instructions. DNA concentration and purity were determined using a NanoDrop Spectrophotometer (Thermo Scientific).

Eight simple sequence repeat (SSR) markers designed for $P$. nigra species were used in this study, namely WPMS04, WPMS07, WPMS09, WPMS12 (VAN DER Scноот et al., 2000), WPMS14, WPMS16, WPMS20 (SMULDERs et al., 2001) and PMGC14 available from the Poplar Molecular Genetics Cooperative database (http://poplar2.cfr.washingthon.edu/pmgc).

PCR reactions were performed as described either in VAN DER SchOOT et al. (2000) (for WPMS04, WPMS07, WPMS09, WPMS12 and PMGC14 markers) or in SMULDERS et al. (2001) (for the rest of the markers). The reverse primers were labelled with four different fluo-

Table 2. - Germination energy (GE) and germination capacity (GC) of progeny derived from different treatments (pollination combinations) using monoecious P. nigra var. nigra trees, expressed as a percentage.

\begin{tabular}{|c|c|c|c|c|c|c|c|c|c|c|c|c|c|c|c|c|}
\hline & \multirow[b]{2}{*}{ Year } & \multicolumn{3}{|c|}{$\mathrm{Mc}_{\mathrm{x}} \times \mathrm{Mc}_{\mathrm{x}}$} & \multicolumn{3}{|c|}{$\mathrm{Mc}_{\mathrm{x}} \times \mathrm{B}$} & \multicolumn{3}{|c|}{$\mathrm{Me}_{\mathrm{x}} \times \mathrm{O}$} & \multicolumn{3}{|c|}{$\mathrm{S} \times \mathrm{Me}_{\mathrm{x}}$} & \multicolumn{3}{|c|}{$M \mathrm{e}_{\mathrm{x}}^{(p p}$} \\
\hline & & NS & $\mathrm{GE}$ & $\mathrm{GC}$ & $\mathrm{NS}$ & GE: & $\mathrm{GC}$ & NS & $\mathrm{GE}^{-}$ & $\mathrm{GC}$ & NS & $\mathrm{GE}$ & $\mathrm{GC}$ & NS & $\mathrm{GE}$ & $\mathrm{GC}$ \\
\hline \multirow[t]{3}{*}{$\mathrm{Mc}_{1}$} & 2009 & 129 & 0.0 & 0.0 & - & - & - & - & - & - & - & - & - & 50 & 10.0 & 12.0 \\
\hline & 2010 & 84 & 52.4 & 47.6 & 93 & 3.2 & 1.1 & - & - & - & 135 & 80.0 & 71.1 & 143 & 25.9 & 18.2 \\
\hline & 2011 & 26 & 46,2 & 38.5 & 100 & 2.0 & 5.0 & 100 & 73.0 & 56.0 & 100 & 83 & 58 & 100 & 31.0 & 24.0 \\
\hline $\mathrm{Mc}_{2}$ & 2009 & - & - & - & - & - & - & - & - & - & - & - & - & 46 & 6.5 & 11.0 \\
\hline \multirow[t]{2}{*}{$\mathrm{Me}_{3}$} & 2010 & - & - & - & - & - & - & - & - & - & - & - & - & 100 & 41.0 & 35.0 \\
\hline & 2011 & 200 & 34.0 & 28.0 & - & - & - & - & - & - & - & - & - & 100 & 7.0 & 13.0 \\
\hline \multirow[t]{2}{*}{$\mathrm{Mc}_{4}$} & 2010 & - & - & - & - & - & - & - & - & - & - & - & - & 13 & 23.1 & 15.4 \\
\hline & 2011 & 186 & 77.4 & 62.4 & - & - & & & - & - & - & - & & 177 & 24.3 & 32.2 \\
\hline \multirow[t]{2}{*}{$\mathrm{Me}_{j}$} & 2010 & - & - & - & - & - & - & - & - & - & - & - & - & 100 & 87.0 & 71.0 \\
\hline & 2011 & 100 & 76.0 & 71.0 & 154 & 58.4 & 57.1 & - & - & - & - & - & - & 100 & 8.0 & 1.0 \\
\hline \multirow[t]{2}{*}{$\mathrm{Me}_{6}$} & 2009 & - & - & - & - & - & - & - & - & - & - & - & - & 50 & 16.0 & 16.0 \\
\hline & 2011 & - & - & - & 98 & 43.9 & 21.4 & 11 & 81.8 & 81.8 & - & - & - & 100 & 15.0 & 14.0 \\
\hline
\end{tabular}

$\mathrm{NS}=$ number of seeds, $\mathrm{B}=$ brother tree, $\mathrm{O}=$ other (distant relative or unrelated) tree, $\mathrm{S}=$ sister tree, $\mathrm{x}=$ index number of monoecious tree, $\mathrm{OP}=$ open pollination. 
Table 3. - Cramer's V coefficient for either germination energy $\left(\mathrm{V}_{\mathrm{GE}}\right)$ or germination capacity $\left(\mathrm{V}_{\mathrm{GC}}\right)$ and either pollination treatment or year of pollination.

\begin{tabular}{cccccccc}
$\begin{array}{c}\mathrm{V}_{\mathrm{it} /} / \mathrm{V}_{\mathrm{irc}} \\
\text { Monoccious } \\
\text { tree }\end{array}$ & \multicolumn{2}{c}{ Specific pollination treatment } & \multicolumn{5}{c}{ Specific year } \\
\hline $\mathrm{Me}_{1}$ & $0.09 / 0.11$ & $\mathbf{0 . 5 9 / 0 . 5 7}$ & $\mathbf{0 . 6 3 / 0 . 5 3}$ & $\mathbf{0 . 5 0 / 0 . 4 6}$ & $0.03 / 0.11$ & $0.04 / 0.14$ & $\mathbf{0 . 3 2 / 0 . 2 3}$ \\
$\mathrm{Me}_{3}$ & - & - & $\mathbf{0 . 2 9} / 0.17$ & - & - & - & $\mathbf{0 . 4 0 / 0 . 2 6}$ \\
$\mathrm{Me}_{4}$ & - & - & $\mathbf{0 . 5 3 / 0 . 3 0}$ & - & - & - & $0.01 / 0.09$ \\
$\mathrm{Me}_{4}$ & - & - & $\mathbf{0 . 5 4 / 0 . 5 7}$ & - & - & - & $\mathbf{0 . 7 9 / 0 . 7 2}$ \\
$\mathrm{Me}_{6}$ & - & - & $\mathbf{0 . 3 9} / 0.36$ & - & - & - & $\mathbf{0 . 3 0 / 0 . 3 2}$ \\
\hline
\end{tabular}

$\mathrm{B}=$ brother tree, $\mathrm{S}=$ sister tree, $\mathrm{x}=$ index number of monoecious tree, $\mathrm{OP}=$ open pollination. Statistically significant associations revealed by $C h i$-square tests are shown in bold.

rescent dyes (FAM, VIC, NED, PET). Four PCR products (four SSR loci with different dyes) were mixed with deionized formamide and GeneScan 500 LIZ size standard (Applied Biosystems). Fragment analysis was done in a genetic analyzer, ABI 310 (Applied Biosystems).

The genetic data obtained were processed with freeware Cervus 3.0 (KALINOWsKI et al., 2007). PCR product sizes of three samples derived from the first two trees observed to be monoecious $\left(\mathrm{Me}_{1}, \mathrm{Me}_{2}\right)$ were used for identity tests. The sizes of PCR products derived from monoecious trees chosen at random were used to analyze the parentage of some of their descendants.

\section{Results}

\section{Germination test}

Percentages of both GE and GC for the progeny derived from different pollination combinations using monoecious $P$. nigra var. nigra trees are summarized in Table 2.

In the first year of investigation (2009), seeds were obtained from the single, self-pollinated monoecious tree $\left(\mathrm{Me}_{1}\right)$ and from both open-pollinated trees $\left(\mathrm{Me}_{1}\right.$ and $\mathrm{Me}_{2}$ ). The GE and GC percentages of seeds derived from open pollination were quite low, ranging from $6.5 \%$ to $12 \%$, and no seeds whatsoever produced by self-pollination germinated.

In the spring of 2010 , the $\mathrm{Me}_{1}$ tree was used in four different crossings. The most successful germination results $(80 \%)$ came from pollinating a female tree with pollen from the $\mathrm{Me}_{1}$ tree, while half the seeds derived from selfing germinated, and GE and GC values of $25 \%$ and $20 \%$ respectively were obtained from seeds coming from open pollination. Only a small number of seeds germinated when tree $\mathrm{Me}_{1}$ was used as the female component. For the other three monoecious trees $\left(\mathrm{Me}_{3}, \mathrm{Me}_{4}\right.$ and $\mathrm{Me}_{5}$ ), only the seeds from open pollination were harvested due to the small number of flowers produced. Germination rates in the different batches of seeds showed wide variation, from 23 to $87 \%$ for GE and from 15 to $71 \%$ for GC.

In 2011, seeds from the different crosses were obtained from all the monoecious trees, with the exception of the tree $\mathrm{Me}_{2}$ and another, $\mathrm{Me}_{6}$. Higher germination rates were obtained in the case of selfing (from $34 \%$ to $77 \%$ for GE and from $28 \%$ to $71 \%$ for GC) in comparison with the open-pollinated mother trees (from $7 \%$ to $31 \%$ for GE and from $1 \%$ to $32 \%$ for GC).

Significant low or medium level associations between the values of $\mathrm{GE} / \mathrm{GC}$ for seed derived from specific monoecious trees and pollination types were demonstrated in most cases, i.e. GE/GC rates depended on the type of pollination method employed. The strongest associations (0.54-0.63) were found in trees $\mathrm{Me}_{1}$ and $\mathrm{Me}_{5}$ in the years 2010 and 2011. Significant associations were also found between the GE/GC rates for seed from particular monoecious trees and the year of pollination (Table 3). They were found mainly in the seeds obtained from open-pollinated monoecious trees and those produced by selfing in the $\mathrm{Me}_{1}$ tree. In one fifth of the crossings, that were carried out, insignificant weak associations $(\Phi=0.01-0.11)$ were observed.

\section{Genetic analysis}

Three samples of fresh leaves collected from different cardinal points of both $\mathrm{Me}_{1}$ and $\mathrm{Me}_{2}$ trees were analysed. Based on genetic analysis using eight microsatellite loci, it was concluded that the samples within each tree were identical.

All SSR analyses confirmed the identity of both parents in controlled pollination. No selfing could be demonstrated in the progeny derived from open-pollinated monoecious trees (Table 4).

Table 4. - Genetic analysis of arbitrarily chosen offspring derived from different crossings.

\begin{tabular}{|c|c|c|c|}
\hline $\begin{array}{l}\text { Ycar of } \\
\text { crossing }\end{array}$ & $\begin{array}{c}\text { Parental } \\
\text { combination }\end{array}$ & $\begin{array}{c}\text { Number of analysed } \\
\text { offspring }\end{array}$ & $\begin{array}{c}\text { Ratc of selling } \\
(\%)\end{array}$ \\
\hline 2009 & $\mathrm{Me}_{1}{ }^{\prime \mu}$ & 13 & 0 \\
\hline 2009 & $\mathrm{Me}_{2}$ & 4 & 0 \\
\hline 2009 & $\mathrm{Me}_{6}$ & 19 & 0 \\
\hline 2010 & $\mathrm{Mc}_{1} \times \mathrm{Mc}_{1}$ & 35 & 100 \\
\hline 2010 & $\mathrm{~S} \times \mathrm{Me}_{1}$ & 35 & - \\
\hline 2010 & $\mathrm{Me}_{1}{ }^{\mathrm{OP}}$ & 18 & 0 \\
\hline
\end{tabular}

$\mathrm{OP}=$ open pollination. 


\section{Discussion}

The main aim of this study was to determine the fertility of both the male and female flowers on six mature monoecious Populus nigra L. var. nigra trees, using four different crossing treatments. We obtained seeds from almost of all of our crossings, i.e. selfing, monoecious tree as either female or male parent, and open pollination of the respective monoecious tree. This is in contrast to VoN MELCHIOR (1967) who found one monoecious clone of Populus nigra var. betulifolia that had no fertile pollen, but the second one could be used as either male or female parent. Moreover, the second clone was selffertile, just as all the monoecious trees used in our study were. Therefore it seems that the possibility of reproductive barriers existing to prevent selfing (both pre- and post-fertilization) has been eliminated (STEBBINS, 1958). Surprisingly, however, no spontaneous selfing was found in the tested seedlings. Even though we only tested a small number of seedlings, we expect that this could be explained by the asynchronous flowering of the male and female flowers and/or a preference for cross-pollination over self-pollination (BATEMAN, 1956; ECKERT and BARrett, 1994; ECKERT and Allen, 1997; MorAndPRIEUR et al., 2003). Moreover, selection among pollen grains may be occurring as a result of influences arising from both pollen donors and maternal plants (MARSHALL et al., 2007).

The observed self-compatibility could be useful in a P. nigra breeding progamme (BENETKA et al., 2012) for establishing parent lines with greater homozygosity. If these proved to be healthy and grew well, they could be used in heterotic breeding, i.e. for obtaining higheryielding biomass plants. Also in fragmented populations of $P$. nigra (LEFÈVRE et al., 1998; HEINZE and LEFÈVRE, 1999) where potential mates are rare, the possible presence of a monoecious black poplar tree with self-compatibility could be advantageous, because just a single individual would be able to sexually reproduce. On the other hand, the self-compatibility of monoecious $P$. nigra trees could be a disadvantage if there is higher probability of inbreeding depression, when the descendants of such a tree would be less competitive than those derived by cross-fertilization.

The lower seed germination rates $(0 \%$ to $80 \%)$ in this study compared to those obtained by KARRENBERG and SUTER (2003), who obtained more than $90 \%$ seed germination in $P$. nigra, could also be, aside from the consequences of possibly different germination conditions, the result of inbreeding depression, since the seeds were obtained by repeated crossings between related trees. Inbreeding depression could cause lower or even zero seed germination due to the occurrence of homozygous, lethally deleterious recessive alleles, which could be manifested at any stage of the life cycle. Lethality is likely to be concentrated in the embryo phase of development in many predominantly outcrossing species because it is here that, for the first time, essential genes are expressed (Husband and Schemske, 1996). The seeds we obtained from monoecious trees germinated, but it is possible that under field conditions seed germination could be poorer, due to fluctuating temperatures and variations in the availability of water (KARRENBERG and Suter, 2003; GuILlOY-Froget et al., 2002).

Germination differences between years in our study, could also be caused by variations in external factors which can influence the maternal plants during seed ripening, especially temperature, water stress, day length, sunlight quality (GUTTERMAN, 1993) and the availability of nutrients (BEWLEY and BLACK, 1994; BRADFORD and NONGAKI, 2007).

In this study, significant associations between GE/GC and pollinating method or year were observed. Moreover, it seems (Table 2) that progeny arising from open pollination using monoecious trees as the female partner have a lower germination energy and capacity in comparison to controlled pollinations where the monoecious tree was used as the male partner. This could be explained by differences in the receptivity of the female flowers and/or the fertility of the pollen. Germination rates were generally higher in seeds derived from controlled pollination than in those from open pollination. This contrasts with the observations of LIENERT and Fischer (2004) who observed a progressive reduction in seed production and germination rates when moving from open pollination to cross-pollination (with one pollen donor) and finally self-pollination, at least in the case of proterandric Swertia perenis. Furthermore, AGUIRRE et al. (2007) observed lower germination rates in seeds from fruiting males and ROTTENBERG (2000) reported significantly poorer pollen fertility and fruit set for a $P$. euphartica bisexual individual compared to ordinary individuals.

The causes of the observed deviations from dioecism were not under investigation nevertheless it is very unlikely that mutation is a cause of monoecism because the results of our genetic analysis do not support this hypothesis. However, it is possible that by using only eight SSR loci and only two monoecious trees for genetic analysis, the results could be distorted. We suppose that crossings made between sibling trees could provide deviations from dioecism as variation from strict dioecism occurs more frequently in small fragmented populations (HuFF and Wu, 1992; HuMEAU et al., 1999). Furthermore, almost all monoecious trees in this study are descended from the same mother tree and therefore it seems that abnormalities in flowering could be genetically determined and inherited, as previously described by HuFF and Wu (1992) and SANTAMOUR (1956).

In conclusion, it has been demonstrated that both male and female flowers of monoecious $P$. nigra var. nigra trees can be fertile, and furthermore that individual monoecious trees are self-compatible. The seeds obtained successfully germinated, but the germination rates varied, depending on the pollination method employed. This new knowledge of the reproductive biology could be applicable in conservation genetic and P. nigra heterotic breeding. Further investigations will be required to determine whether the seedlings will grow to maturity and successfully reproduce themselves, and then what kind of flowers, male, female or both, they will have. 


\section{Acknowledgements}

The authors gratefully acknowledge MiroslavA KŘÍŽOVÁ for carrying out the DNA analysis, VOJTĔCH BENETKA for fruitful discussions and MALCOLM RUSSELL for helping with English grammar and spelling. This research was financially supported by the Ministry of the Environment of the Czech Republic (grant no. 0002707301) and the Ministry of Agriculture of the Czech Republic (grant no. QH81160).

\section{References}

Alba, N., D. Macaya, C. Maestro, J. Climent and S. C. GONZÁLEZ-MARTíNEZ (2008): Occurrence of hermaphroditism in Populus alba L., a mostly dioecious riparian tree, pp. 5 in Poplars, willows and people's wellbeing. 27-30 October 2008, Beijing, China.

Aguirre, A., M. VAllejo-Marín, L. SAlazAr-Goroztieta, D. M. ARIAS and R. DiRzo (2007): Variation in sexual expression in Jacaratia mexicana (Caricaceae) in southern Mexico: Frequency and relative seed performance of fruit-producing males. Biotropica 39: 79-86

BARRETT, S. C. H. (1992): Gender variation and the evolution of dioecy in Wurmbea dioica (Liliaceae). J Evol Biol 5: 423-444.

BATEMAN, A. J. (1956): Cryptic self-incompatibility in the wallflower: Cheiranthus cheiri L.. Heredity 10: 257-261.

BenetKa, V., K. Novotná and P. S̆TOChlová (2012): Wild populations as a source of germplasm for black poplar (Populus nigra L.) breeding programmes. Tree Genet Genome 8: 1073-1084.

BenetKa, V., M. Pospís̆Ková, F. VRÁtnÝ and M. TKaczYKovÁ (2008): Inbreeding Depression in the Fullsib Offspring of Populus nigra L. Silvae Genet 57: 202-210.

BEWLeY, J. D. and M. Black (1994): Seeds: physiology of development and germination. Plenum Press, NY.

BRADFORD, K. J. and H. NoNOGAKI (2007): Seed development dormancy and germination. Blackwell, Oxford.

BRunner, A. M. (2010): Reproductive development in Populus, pp. 155-170. In: Genetics and genomics of Populus, Plant genetics and genomics: Crops and models 8 . Part III, edited by S. JANSSON, R. P. BHALERAO and A. T. Groover, Springer, New York, USA.

CAMPO, E. (1963): Flower morphogenesis and embriogeny in a bisexual Populus deltoides. Giorn Bot Ital 70: 212-219.

CASE, A. L. and S. C. H. BARRETT (2001): Ecological differentiation of combined and separate sexes of Wurmbea dioica (Colchicaceae) in sympatry. Ecology 82: 2601-2616.

Cronk, Q. C. B. (2005): Plant eco-devo: the potential of poplar as a model organism. New Phytol 166: 39-48.

Dellaporta, S. L. and A. Calderon-Urrea (1993): Sex determination in flowering plants. Plant Cell 5: 1241-1251.

DelPH, L. F. and D. E. Wolf (2005): Evolutionary consequences of gender plasticity in genetically dimorphic breeding systems. New Phytol 166: 119-128.

ECKerT, C. G. and M. Allen (1997): Cryptic self-incompatibility in tristylous Decodon verticillatus (Lythraceae). Am J Bot 84: 1391-1397.

Eckert, C. G. and S. C. H. BARReTt (1994): Post-pollination mechanisms and the maintenance of outcrossing in self-compatible, tristylous, Decodon verticillatus (Lythraceae). Heredity 72: 396-411.
FAO [Food and Agriculture Organization of the United Nations] (1980): Poplars and willows in wood production and land use. FAO, Rome.

Guilloy-Froget, H., E. Muller, N. Barsoum and F. M. R. Hughes (2002): Dispersal, germination, and survival of Populus nigra L. (Salicaceae) in changing hydrologic conditions. Wetlands 22: 478-488.

GutTERMAN, Y. (1993): Seed germination in desert plants. Adaptions of desert organisms. Springler, Berlin.

Heinze, B. and F. LEFÈVRE (1999): In situ restoration genetics of riparian populations of $P$. nigra, pp. 43-50. In: Populus nigra Network, edited by J. TURoK, F. LeFÈVRe, S. DE VRIES, B. Heinze, R. VolosyanchuK, E. LIPMAN and compilers, IPGRI, Rome, Italy.

Heslop-HARRIson, J. W. (1924): Sex in the Salicaceae and its modification by eriophyid mites and other influences. Brit J Exp Biol 1: 445-472.

HuFF, D. R. and L. Wu (1992): Distribution and inheritance of inconstant sex forms in natural populations of dioecious buffalograss (Buchloe dactyloides). Am J Bot 79: $207-215$.

Humeau, L., T. Pailler and J. D. Thompson (1999): Variation in the breeding system of two sympatric Dombeya species on La Réunion island. Plant Syst Evol 218: 77-87.

Humeau, L., T. PAiller and J. D. Thompson (2000): Variation in gender and flower-size dimorphism in the dioecious tree Dombeya ciliata, an endemic to La Réunion island. Biotropica 32: 463-472.

Husband, B. C. and D. W. Schemske (1996): Evolution of the magnitude and timing of inbreeding depression in plants. Evolution 50: 54-70.

İsFENDIYAROĞLU, M. and E. ÖZEKER (2009): Inflorescence features of a new exceptional monoecious Pistacia atlantica Desf. (Anacardiaceae) population in the barbaros plain of İzmir/Turkey. Int J Plant Prod, 3: 93-98.

Jovanović, B. and A. Tucović (1962): An unusual occurrence of monoecism in Populus nigra L. Topola 6: 46-50.

Kalinowski, S. T., M. L. TAPER and T. C. Marshall (2007): Revising how the computer program CERVUS accommodates genotyping error increases success in paternity assignment. Mol Ecol 16: 1099-1106.

KARREnBerG, S. and M. Suter (2003): Phenotypic tradeoffs in the sexual reproduction of Salicaceae from flood plains. Am J Bot 90: 749-754.

Lefìvre, F., A. Legionnet, S. De VRIES and J. TuroK (1998): Strategies for the conservation of a pioneer tree species, Populus nigra L., in Europe. Genet Sel Evol 30: 181-196.

Lester, D. T. (1963): Variation in Sex Expression in Populus tremuloides Michx. Silvae Genet 12: 141-151.

LiENERT, J. and M. Fischer (2004): Experimental inbreeding reduces seed production and germination independent of fragmentation of populations of Swertia perennis. Basic Appl Ecol 5: 43-52.

Marshall, D. L., J. Reynolds, N. J. Abrahamson, H. L. Simpson, M. G. Barnes, J. S. Medeiros, S. Walsh, D. M. Oliveras and J. J. AvRITT (2007): Do differences in plant and flower age change mating patterns and alter offspring fitness in Raphanus sativus (Brasicaceae)? Am J Bot 94: 409-418.

Morand-Prieur, M. E., C. Raquin, J. A. Shykoff and N. Frascaria-Lacoste (2003): Males outcompete hermaphrodites for seed siring success in controlled crosses in the polygamous Fraxinus excelsior (Oleaceae). Am J Bot 90: 949-953. 